\title{
A Comparative Analysis of the Femicide of Migrant Domestic Workers in Bahrain and Lebanon:
}

\section{The Systemic Abuse of Foreign Female Labourers}

\author{
Marya Al-Hindi \\ MSc in Criminology and Criminal Justice
}

\begin{abstract}
Gender-based violence (GBV) is becoming a major topic of criminological concern. This article examines the factors contributing to the abuse of female Migrant Domestic Workers (MDWs) by their employers in two Middle Eastern countries, Lebanon and Bahrain. It pinpoints the law as the structure that maintains the slavery-like conditions that facilitate the systematic violence towards MDWs in Bahrain and Lebanon. It also looks at how processes of criminalisation cement MDWs in their precarious positions, subject to un-investigated femicide. Therefore, this article proposes to view femicide as a state of existence resulting from a wider societal structure as opposed to a single act condensed in time and space. The article adopts an intersectional approach to GBV, which draws attention to the states' role in facilitating the exploitation of MDWs. It also calls for the inclusion of MDWs in the Lebanese and Bahraini labour laws. By acknowledging the multi-dimensional abuse which ultimately results in the death of MDWs, the article concludes that the governments of the receiving and sending countries must do more to protect their most marginalised subjects. Moreover, criminologists should include MDWs as a criminalised group in more of their academic endeavours.
\end{abstract}

Keywords: Femicide, Gender-based Violence, Migrant Workers, Middle East, Kafala System 


\section{Introduction}

Stories of gender-based violence frequently shock communities around the world. Women situated at the fringes of their respective societies due to their ethnicity, socio-economic status, sexual orientation or the intersection of these identities, are particularly vulnerable targets of gender-based violence and the macro-societal structures that perpetuate it. The form of genderbased violence which will be analysed in this article is the femicide of Migrant Domestic Workers (MDWs). This analysis will compare the structural factors which 'produce' a continuous state of femicide in Lebanon and Bahrain. The reasons for the focus on femicide are twofold: firstly, it draws attention to the systematic abuse of (predominantly female) MDWs in the host countries and secondly, it is the endpoint of a larger system of exploitation starting at the country of origin.

The article will explore the framework to be used, by discussing the criminological literature on femicide as well as sketching the contours of the 'Kafala system' which positions MDWs in a perpetual state of abuse. In both Lebanon and Bahrain, the law is the institution through which traditional gender categories are maintained. In order to reach this conclusion, this article will firstly show the criminalisation of migration, specifically of poor, black, female migrants, combined with the excessive policing of women in both Middle Eastern countries leaves MDWs subject to unchecked abuse and violence. Secondly, by delegating responsibility for them to their individual employers, the state relegates MDWs to their specific roles as domestic workers, deeming their abuse as a private matter beyond the remit of the state. The sense of ownership that employers have over MDWs is facilitated by the state's neglect of the marginalized group, cementing their precarious position as commodities, and making them vulnerable to unlimited forms of exploitation. The article will conclude that the law itself maintains the subjugation and abuse of MDWs.

A comparative criminology approach will be used in this article. According to Giddens (1979, p. 3), social scientific inquiry should always investigate and challenge the spatio-temporal assumptions surrounding a given phenomenon. Such an approach processes and critiques a status $q u o$, analyses what can be improved, and challenges what has been accepted as 'truth'. The aim of the article is not to establish universal truths, but to discover 'how particular factors can make some women more vulnerable than others' (Mirza 2016, p. 595). This essay uses two Arab countries because of their geographical, cultural, and historical similarities (Gorman 2007, p. 100). 
The subsequent similarity in criminal justice systems between the two allows for the attainment of solid conclusions (Hundle 2019). Despite being the two Kafala practicing countries with the most information available, there is relatively limited information on the topic due to underreporting, government cover-ups, and facilitation of this exploitation by the law. Subsequently, the aim of this essay is not to provide an exhaustive account, but to provide a starting point to prompt further research.

\section{Theoretical Framework and Context}

\subsection{Femicide: A Definitional Conundrum}

The definition of femicide has been a focal point of academic debate. Its most rudimentary account defines femicide as ‘the misogynous killing of women by men' (Radford \& Russel 1992, p. 3). However, this cannot account for the woman-on-woman violence which many MDWs face. This is not to neglect the exploitative conditions set by men, or that other women abuse MDWs; this form of abuse occurs mainly in the domestic sphere where the 'Madame' has control over the MDWs' living situation (Hamill 2012, p. 16). The criminological approach to GBV often interprets femicide as a part of homicide (Corradi et al. 2016, p. 981), which neglects the factors cementing certain gender roles and abstracts the conditions in which patriarchy is 'crossed through and interacts with other power structures like race, class, age and disability status' (Hester, Kelly \& Radford 1996, p. 65). Corradi et al. (2016, p. 985) defined femicide as 'the result of a violent interaction whereby a woman or a girl dies i.e. an extreme and direct form of violence as part of an interpersonal process within a larger social context'. This definition is also limited, however, because defining femicide as an interpersonal process 'fails to cover the arduous process leading up to her death' (Shalhoub-Kevorkian 2003, p. 581).

Instead, this article attempts to address the problematic social context that MDWs find themselves in, by viewing femicide as encompassing a global social structure that 'recreates, maintains, and justifies a pervasive, inhumane social abuse' (Shalhoub-Kevorkian 2003, p. 582). Shalhoub-Kevorkian's (ibid.) definition of femicide extends the concept of death in femicide to more than the mere 'inability to breathe' (ibid., p. 581); instead, it is also an abusive mode of existence imposed on women by global and macrolevel structures while they are still alive. In this view, victims of femicide exist in a mode of 'death-in-life' (ibid.). Looking at this abuse as 'a cause and a consequence of inequality in patriarchal societies, serving to control women as a sex class' 
(Radford \& Russel 1992, p. 3) allows us to incorporate the structural violence into the investigation.

Ultimately, Shalhoub-Kevorkian's (2003) definition is the most relevant to the ends of this article, because it encompasses the global system which makes a woman's life as a domestic worker unconducive to normal standards of living. This definition allows for a link from individual-level crime and violence against MDWs to macro-level power structures that facilitate it.

According to Cook (2016, p. 342), criminologists should appreciate that the discipline is a 'product of White, economically privileged' male experience. By contrast, an intersectional approach gives voice to 'those who have historically been silenced [and] is concerned with socially structured systems of inequality' (Sokoloff \& Burgess-Proctor 2011, p. 237). There is an 'absence in the cross racial feminist analysis' (Hundle 2019, p.48) connected to histories of the Global South, and drawing attention to their particular situations 'sheds light on new universals of feminist practice [...] [challenging] us to see feminism in new ways' (ibid., p. 49).

Using an intersectional approach which doesn't see communities as 'objects of intervention [...] [but] subjects in their own rights' (Wade 2011, p. 32), I chose two Middle Eastern countries as the subjects of inquiry. This emphasises that the aim is not to colonise the experiences of the women discussed in this article, but to situate it in the larger context of femicide. When writing about the Middle East, avoiding orientalist forms of writing is key, such as constructions of the 'abusive "Madam" [sic.] and (the male Arab employer as a sexual predator)' which contribute to the narrative of 'abusive Arabs' (Pande 2013, p. 435); the exploitation of women is a global phenomenon.

\subsection{Contours of the Kafala System}

As of 2016, there were 250,000 female MDWs in Lebanon (Insan Association 2016, p. 8; Jureidini 2002), and 76,249 female MDWs in Bahrain (Migrant Rights 2018); the women originate mainly from Ethiopia, Sri Lanka, and the Philippines (Insan Association 2016). Femicide of MDWs has been increasing rapidly in Lebanon with 'the bodies of 138 migrant domestic workers [...] repatriated between January 2016 and April 2017' (Su 2017). The rate at which MDWs are 
being killed in Lebanon has also doubled in recent years (Amnesty International 2018). This worrying phenomenon will be explained in this article through an exploration of the Kafala system.

The Kafala (or sponsorship) system is particular to the Middle East and has been likened to 'modern day slavery' (Jureidini 2010, p. 156; Hall 2019). According to Article 7 of The Lebanese Labour Law, domestic workers are excluded from the protections given to ordinary employees (Hamill 2012, p. 25), and are instead governed by the Kafala system which delegates legal and economic responsibility over an individual MDW to an individual employer (Pande 2013, p. 418). Private agencies 'contract' with other groups in the sending countries to bring female migrant domestic workers into Lebanon (Jureidini 2010). MDWs sign contracts with particular employers (ibid., p. 143), which bind them to the employer for a period of two years - a fixed time increment universal to all countries using the Kafala system. The individual hiring MDWs becomes the sponsor or 'Kafeel', and the contract signed is often in a language that MDWs do not read, nor understand (Hamill 2012, p. 12). In addition, MDWs are often charged a large starting fee, which makes them indebted to the agency which brought them to the country (Insan Association 2016).

Politically, Bahrain seems to have taken steps to improve the situation of MDWs, being the first country in the Middle East to have abolished the Kafala system controlling MDWs (Harmassi 2009). Bahrain was also labelled the 'most-committed' of the labour-receiving Gulf countries to 'improving migrant labour practices' (Human Rights Watch 2019, p. 2). Despite this, MDWs in Bahrain have reported 'working up to 19-hour days, with minimal breaks and no days off [...] [and being] prevented from leaving their employer's homes, and [not] provided with adequate food' (Human Rights Watch 2015). These reports imply that despite the Kafala system having been repealed in Bahrain, its exploitative features prevail.

Therefore, Lebanon and Bahrain maintain similar systems — the only difference is that Bahrain supposedly repealed Kafala in 2009 (Harmassi 2009). Nonetheless, Bahrain was selected as a subject of enquiry for this study because as the only Middle Eastern country that has tried to review the system, it will allow us to investigate whether the Kafala system is 'merely' a legal institution or a more pervasive social structure. Lebanon, on the other hand, still maintains the legal frameworks of the Kafala system and thus seemingly serves as a counterpoint to Bahrain. In 
reality however, as this essay will show, the two countries are very similar in their exploitation of MDWs.

Despite Bahrain's abolishment of the system in 2009, Human Rights Watch (2015) found that the implemented reforms are not exhaustive in key issues of MDWs and even those areas that are covered lack adequate implementation. For example, MDWs still do not have codified 'maximum daily and weekly work hours' (Human Rights Watch 2019, p. 6) and do not enjoy mandated days off. Furthermore, MDWs are still subject to physical and sexual abuse in the home and their cases often only proceed timidly through the criminal justice system (ibid., p.98). In both countries, MDWs' entry visa as well as residence and work permits include the sponsor's name; the sponsor assumes financial and legal responsibility for the MDW while she is in the country (Hamill 2012, p. 11). In this way, the Kafala system represents an 'outsourcing of management of migrant labour from the state to the citizen' (Hamadah 2020). Both countries tolerate the physical and sexual abuse of MDWs, them 'not receiving the promised wage (on time)', the 'unstructured nature of work', them working 'long hours without time off', and restrictions on their mobility (Pande 2013, p. 426). Often, one MDW will be burdened with multiple roles in multiple locations (ibid., p. 427).

The complicity of the sending and host countries in the abusive state which MDWs find themselves in as well as the atomisation of power over the MDW's migration and circumstances in the 'Kafeel', fits with the above definition of femicide as a perpetual state of abuse facilitated by macro-societal structures. Economic interests of the sending and receiving countries propel women into a 'death-in-life' (Shalhoub-Kevorkian 2003) state whereby they are subject to abuse and femicide.

\section{Claim One: MDWs are Criminalised Through the Kafala System}

The criminalisation of MDWs facilitated through the Kafala system is a way of policing and maintaining gender boundaries. Criminalisation of persons can be defined as the process of 'turning a section of the population into criminals' (Gordon 1983, p. 138). Strobl (2008, p. 166) describes the forces that contribute to criminalisation as 'a process involving the decentring and diffusion of legal forms and practices across agencies and jurisdictions'. Criminalisation places people outside the protections of the law, leaving their freedom severely restricted. Lebanon, for example, has a long history of discriminating against foreigners, and in the COVID-19 pandemic, 
has created new laws restricting the ability of MDWs to be tested (Azhari 2020). Subjecting certain groups to differential treatment under the law is a process of criminalising migrants (Global Detention Project 2018). This section proceeds to analyse both Lebanon's and Bahrain's approaches to the abuse of MDWs at the hands of their employers. The section ultimately concludes that both countries perpetuate the maintenance of gender boundaries, and continue to criminalise MDWs as both foreigners and women.

The criminalisation of migrants results in their marginalisation within society, leaving MDWs to face the triangular jeopardy of being 'foreign', women and 'criminal'. This issue is not limited to the Middle East. Since the turn of the millennium, the illegal migrant workers have become a 'useful and profitable category, that $[\ldots]$ serves to create and sustain a legally vulnerable and tractable and cheap reserve of labour' (Pande 2013, p. 438). Factors such as 'poverty, lack of economic opportunity at home and demand abroad allows traffickers to exploit persons in need of income' - further cementing their criminal status (Beydoun 2006, p. 1013).

The 'feminization of poverty' and the 'proliferation of organized crime, increases the number of women who are victim to prostitution and trafficking' (ibid.). The feminisation of poverty is defined by the European Institute for Gender Equality (EIGE) as the 'increasing incidence and prevalence of poverty among women compared to men, as a result of structural discrimination that affects women's lives' (European Institute for Gender Equality 2000). The fact that many of the women living in poverty are 'uneducated and have no formal training', in addition to the reluctance of society to accept new forms of gender roles, means that the cyclical nature of their poverty will continue as they are forced into domestic and other kinds of servitude (Beydoun 2006, p. 1014). Global hierarchies are evident in this social context as the consensus imagines these women as a disposable workforce and public discourse depicts them as 'deviant and therefore undeserving of state protection' (Pickering 2007, p. 48). In globalizing times, MDWs basically become 'a commodity for sale and apt servitude or other forms of exploitation' (Beydoun 2006, p. 1010). This shows the salience of an abusive global economic system, dependent on female labour, in criminalising MDWs (Strobl 2008). Subsequently, MDWs are situated at the margins of their host society, making them 'fitting' targets of violence and abuse.

The particularity of the Arab world is the excess policing of women, especially in conservative Muslim countries, where "patriarchal community structures [like] religious 
communities and elite community leaders often fail women survivors' (Hundle 2019, p. 49). There is a racialized gender discourse of femininity which dehumanizes women, especially those pertaining to ethnic minorities (Garcia-Del Moral 2018, p. 929). The systematic deaths of MDWs in the Arab world is reflective of the intersection of societal and institutional misogyny and racism in the region (Perry 2006; Mahdavi \& Sargent 2011). Garcia-Del Moral (2018, p. 932) notes that 'racialised gender discourses of femininity mark[s] [...] women as [immoral and] disposable'. This intersection of gender and race leads to MDWs being considered 'black, female, foreign and illegal' (Beydoun 2006, p. 1018). The context of 'restrictions like limits on right to leave employers house outside work hours, confiscation of passports, forced confinement, and restrictions on their ability to reside independently' (Insan Association 2016, p. 8) means that MDWs are deemed criminals if they attempt to escape violence. The criminalisation of MDWs as illegally trafficked, as well as the excessive control over women in society, leaves their freedom severely restricted. In the context of COVID-19, families are confined to homes, and MDWs 'have been forced into more intensive and dangerous work' (Chulov 2020); they are not allowed to speak to their families, are not given a day off, and are not paid (Massena 2020).

The lack of protection of MDWs under the countries' labour laws means that both countries render MDWs vulnerable to being criminalised as both 'women' and 'foreign', either obligated to endure abusive conditions in their employers' homes, or forced into illegality by running away. MDWs are constrained by the dyadic dependency on their employer for their immigration status as well as Lebanon's and Bahrain's dependency on foreign workers. Thus, the MDW cannot enter or leave the country, nor transfer employment without written permission from the Kafeel (International Labour Organisation 2012, p. 1). If the sponsor withdraws at any time, the MDW no longer has legal immigration status (Strobl 2008, p. 169). Additionally, if they protest their terms of employment, the Kafeel can unilaterally lower their wages, abuse them, refuse to renew their contract or petition for their deportation, which results in a loss of their legal residency and possible criminal charges (International Labour Organization 2012, p. 4). If an MDW attempts to leave to flee their abuser, their employer may use tactics which would release themselves from legal obligations owed to the MDW and report them missing or accuse them of stealing. When MDWs have been successful in fleeing abuse, they are likely forced into illegal work, or as Pande (2013, p. 415) states, become part of the 'new population of readily exploitable workers ("illegal workers")' who are cheap, flexible and vulnerable. Due to lack of legal recourse, they are often 
caught and deported for overstaying their residency visa (Strobl 2008, pp. 173-174). This means that the two options for MDWs are to either endure abuse at the hands of their employer or flee and risk living in the country illegally. Mirza (2016, p. 600) looks at the lack of 'immigration status as a prominent feature of $[\ldots]$ abuse', since it becomes a 'source of control and intimidation'. This reinforces the idea of femicide as a perpetual mode of existence as opposed to an event condensed in time and space (Shalhoub-Kevorkian 2003). The status of MDWs as foreign in conjunction with the legal centralisation of migration management in the Kafeel provides the Kafeel with a plethora of abusive tactics such as the threatening of deportation. MDWs' immigration status is completely in the hands of their Kafeel. For abused MDWs, their presence in the country is conditional on enduring different forms of abuse.

Bahrain has formally abolished the Kafala system, meaning that there are less legally mandated restrictions on MDWs' freedom, but the 'use of local police stations to handle labourrelated disputes represents a criminalisation of housemaids even when their behaviour is not criminal' (Strobl 2008, p. 165). Police are unable to deal with the larger socio-political, economic and legal issues surrounding the problem, so housemaids tend to be criminalised and incarcerated even when it is inappropriate (ibid., p. 179). These two Middle Eastern countries are heavily dependent on foreign labour yet remain societally and institutionally racist (Perry 2006). Being 'black, female, foreign and illegal' (Beydoun 2006, p. 1018), even in a country which has abolished the Kafala system, is still societally criminalising. In the same process as above, the limited protections that MDWs have under Bahraini labour law, means that they are subject to a similar choice, either living under abusive conditions in their employers' homes, or fleeing and taking up illegal work in the country. Both situations result in MDWs possibly being tried in the criminal justice system, which cements the idea that they are criminals. Bahrain has taken steps in the right direction but the policewomen that 'play [a] central role in handling [MDWs]' are still a symptom of the larger problem of the criminalisation of MDWs (Strobl 2008, p. 180). Ultimately, until MDWs are adequately protected under the labour law, they are vulnerable to being criminalised as 'women', as well as 'foreign': as a result, their femicide will continue.

The justification for continued employment of MDWs is the countries' dependence on foreign female labour (ibid., p. 166), and the possibility of Lebanese and Bahraini women to join the workforce (International Labour Organisation 2012, p. 7). This justification aligns with the 
definition of femicide discussed above, as it points to the economic structures that facilitate microlevel violence dispersed across time and space. In order to upend this state of death-in-life, both countries must include MDWs in their labour law (to give them the common standard of living that they deserve) and review their anti-trafficking legislation. Treating MDWs as criminals is a human rights violation to be remedied by abolishing the Kafala system.

\section{Claim Two: How Legal Frameworks Maintain Traditional Gender Roles}

The previous section detailed systemic reasons why MDWs have become a criminalised commodity in Lebanon and Bahrain through Kafala. This section addresses how the law is the institution through which traditional gender categories are maintained. By abandoning their responsibility to limit the exploitation of foreign labourers, the governments relegate these women to their homes, deeming them beyond the protections of the law. The issue of MDWs in both countries is deemed as one that should be dealt with either in the individual contractual relationship between the Kafeel and the MDW, or through the criminal justice system. This section outlines how the government neglects its responsibility to protect these marginalised women, and the way this perpetuates their vulnerability to subjugation at the hands of their employers. The state's neglect of MDWs leaves them as their employers' possessions, contributing to the way that traditional gender categories are maintained.

The role of the government is to 'facilitate a context within which women can reduce their vulnerabilities and respond to their conditions in a manner that reflects their constraints and needs' (Mirza 2016, p. 606). Despite the state's responsibility to protect vulnerable women, host governments have not developed 'effective measures to address the failure of the police and the justice system to prevent, investigate and punish' any crimes committed against MDWs by their sponsor. In effect, this means that 'the perpetrators enjoy impunity for their actions' (Garcia-Del Moral 2018, p. 943). In the context of international flows of labour, this directs attention to the state, as a site that 'reproduces the mutual construction of race and gender' (ibid., p. 931) by facilitating the entry and exploitation of these women as a result of economic interests in cheap labour.

By making the sponsor legally responsible for the migrant, the 'state responsibility for "alien surveillance" is passed onto the "Madame" who becomes the mediator between the state and domestic workers' (Pande 2013, p. 17). This absolves the government from providing labour 
protection (Mahdavi \& Sargent 2011, p. 10) and allows the country to 'abdicate responsibility to protect the rights of migrant workers by delegating to sponsors the subjective power to determine a workers immigration status' (International Labour Organisation 2012, p. 5). Subsequently, 'victims exist in a political vacuum where governmental assistance and protection was never extended' (Beydoun 2006, p. 1038). In trapping MDWs in this vacuum, governments facilitate femicide as a state of existence. The privacy of the home is a sphere that the government is reluctant to get involved in, further marginalizing the women who the government is meant to protect (Corradi et al. 2016, p. 983; Jureidini 2010, p. 155). Compounded by the costs of exit, which include 'economic destitution, fear of family and community ostracism' (Mirza 2016, p. 597), some women fear returning home because of the shame of returning without enough money to pay off the initial debt they incurred to the agencies or traffickers (Pande 2013, p. 422). Ultimately, the delegation of responsibility to the employers means that the government can overlook their human rights responsibilities, while justifying the continued exploitation of these women through notions of economic benefit to the country and a lack of jurisdiction over the domestic sphere.

Related to the notion of femicide, the government's neglect of these vulnerable women needs to be situated 'in the context of the role of family, society [and] structural conditions' (Barberet 2014, p. 84). Maureen Cain (1990, p. 3) argues that women are seen as 'Others', who are to be 'owned, given away, disciplined, coerced and marked with good or bad intentions'. The dehumanizing tendency to regard MDWs as deserving of different standards of rights, constructs and validates the larger societal and official discourse of their 'ownership' by employers (Insan Association 2016, p. 12). Because the sponsors paid a purchase fee, the idea that MDWs are objects to be owned perpetuates the paternalistic narrative, and further marginalises MDWs (Pande 2013, p. 428). The disposable nature of domestic work is reflected in the government's lack of protection for MDWs, as well as in societal perceptions that women's 'labo[u]r that is not valued and is sometimes invisible' (Barberet 2014, p. 83). MDWs are often uneducated and have no formal training, since societies are hesitant to accept new forms of gender roles other than housekeeper and childminder, the cyclical nature of feminization of poverty continues (Beydoun 2006, p. 1014). MDWs in the Kafala system are not viewed as women but rather as private property in a larger neoliberal economic structure. 
Despite the abolishment of the Kafala system in Bahrain, MDWs are still relegated to an area where their situation warrants certain treatment (or lack of treatment) by the law, leaving them virtually helpless and 'owned' by their sponsor. Instead of being a protector of MDWs, the law is the institution that maintains them as possessions of those in power, trapping them in a state of femicide. MDWs in Lebanon have de facto no recourse to police services, and often have to depend on Non-Governmental Organisations (NGOs) and social workers when faced with abuse or situations unconducive to their survival (International Labour Organization 2012, p. 4). There is no motivation by the government to alter this system nor its understanding that these women are disposable because of the economic benefits this system provides.

Despite Bahrain's abolishment of the Kafala System, the government still has not included domestic workers under the labour law, leaving any disputes between the MDW and her employer to be handled by the police. Strobl (2008, p. 180) notes that Bahraini policewomen in this field are 'empowered to be authorities but only to keep men and women's roles in society delineated'. In other words, they are placed in situations of power, but only to the extent that they deal with disputes regarding the home, which the government has neglected. Strobl (ibid.) further claims that these policewomen are simultaneously 'symbols of progressive female roles in Bahrain, [...] [and] re-enforcing [sic.] social customs that perceived women as suitable for opposite roles within private domestic spheres'. By abandoning their responsibility to protect MDWs, the state plays the minimised role ascribed to it by neoclassical economics thereby perpetuating their image as 'property' of their employers. The Lebanese state maintains the economic benefit, relegating MDWs to their status as possessions to be owned by the employer and trapped in their domestic servitude. The Bahraini system has increased protections for MDWs, yet by being dealt with by an all-woman police force, MDWs are simultaneously criminalised as well as trapped again in their role as domestic servants. In both countries, the absence of meaningful jurisdictions on MDWs' rights traps MDWs in a state of femicide, as discussed above.

Ultimately, the legal system is one of the institutions through which traditional gender categories are maintained. By neglecting the responsibility to protect trafficked and non-trafficked MDWs, the state delegates responsibility to employers, who enforce unsupervised patriarchal control over these women. This sets off a discourse of the 'abusive madame', distracting attention from the shortcomings of state provision of protection. It can be reliably claimed in both Bahrain 
and Lebanon that keeping migrant domestic workers trapped in the home, and subject to complete supervision with no recourse to public aid, reinforces the idea that women are meant to be limited to the domestic sphere. The fact that MDWs are not included in the labour law and instead 'owned' by their sponsors provides room for perpetrators of violence to oppress the women with little-tono consequences (Garcia-Del Moral 2018, p. 943). Finally, the legal systems in both countries perpetuate notions of the weak, domicile women who are meant to only do domestic work, maintaining gender categories.

\section{Conclusion}

The aim of this article was to draw attention to the systemic factors which lead to the femicide of Migrant Domestic Workers in two Middle Eastern countries: Bahrain and Lebanon. Processes of criminalisation leave MDWs labelled with stereotypes of illegality and inferiority; in the social context of excessive control of women, this means that MDWs are confined to the home and forced to perpetuate their gender's 'role'. The law is one of the factors that contributes to the subjugation of these women, as the government avoids its responsibility to protect, instead delegating exclusive control over women to individual employers. This leaves MDWs vulnerable to unchecked exploitation and abuse, with no access to legal protection. By criminalising MDWs and providing a legal framework that perpetuates traditional gender roles, the Kafala system traps MDWs in a perpetual state of femicide. These processes are facilitated by wider global economic structures and both countries' dependencies on cheap labour.

Further research may look at the techniques of rationalisation which occur when these women are systematically abused (Sykes \& Matza 1957), or 'immigration detention centres' (Lee, Johnson \& McCahill 2018, p. 20) in which MDWs are detained. Many questions remain: Should Bahrain be lauded as a progressive example or has it merely implemented a Kafala 2.0? Under what conditions could Lebanon ever abolish the Kafala system and include MDWs in the Labour Law? How has the COVID-19 pandemic affected the femicide of MDWs in the Gulf? This article is especially important in a context where the numbers of MDWs entering the countries have been steadily increasing, and rampant poverty in the home countries is allowing smugglers to capitalise on destitute populations. More comparative research is necessary to fill the gap surrounding the relationship between host and sending countries, as well as the trafficking rings which make this exploitation possible. 


\section{References}

Amnesty International 2018, End Kafala: Justice for Migrant Domestic Workers in Lebanon, viewed 11 September 2020, <www.amnesty.org/en/latest/campaigns/2019/04/lebanonmigrant-domestic-workers-their-house-is-our-prison/>.

Azhari, T 2020, 'Undocumented in Lebanon: No Papers, No Coronavirus Test', Al Jazeera News, viewed 28 March 2020, <https://www.aljazeera.com/news/2020/03/undocumented-

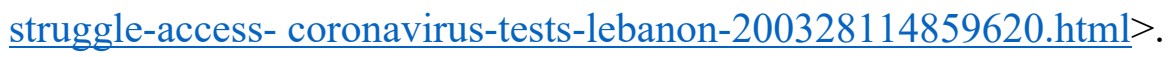

Barberet, R 2014, Women, Crime and Criminal Justice: A Global Enquiry, Routledge, London.

Beydoun, KA 2006, 'The Trafficking of Ethiopian Domestic Workers into Lebanon: Navigating Through a Novel Passage of the International Maid Trade', Berkeley Journal of International Law, vol. 24, pp. 1009-1045, DOI 10.15779/Z38WD3S.

Cain, M 1990, 'Towards Transgression: New Directions in Feminist Criminology', International Journal of Sociology of Laws, vol. 18, no. 1, pp. 252-273, viewed 11 September 2020, $<$ http:/www.ncjrs.gov/App/publications/abstract.aspx?ID=122722>.

Chulov, M 2020, 'Pandemic Raises Fears Over Welfare of Domestic Workers in Lebanon', The Guardian, viewed 16 April 2020, < development/2020/apr/16/pandemic-raises-fears-over-welfare-of-domestic-workers-inlebanon?fbclid=IwAR3347ulQv4mVnUKYTUYns3hy-PoRFPKTMzbI5CdgJXDvRwDuxLY1bc8wM>

Cook KJ 2016, 'Has Criminology Awakened from its “Androcentric Slumber”?', Feminist Criminology, vol. 11, no. 4, pp. 334-353, DOI 10.1177/1557085116660437.

Corradi, C, Marcuello-Servós, C, Boira, S \& Weil, S 2016, 'Theories of Femicide and their Significance for Social Research', Current Sociology, vol. 64, no. 7, pp. 975-995, DOI $10.1177 / 0011392115622256$.

European Institute for Gender Equality (EIGE) 2000, Feminisation of Poverty, viewed 11 September 2020, <eige.europa.eu/thesaurus/terms/1133>.

Garcia-Del Moral, P 2018, 'The Murders of Indigenous Women in Canada as Feminicides: Towards a Decolonial Intersectional Reconceptualization of Femicide', Signs: Journal of Women in Culture and Society, vol. 43, no. 4, pp. 929-954, DOI 10.1086/696692.

Giddens, A 1979, Central Problems in Social Theory: Action, Structure and Contradiction in Social Analysis, Palgrave MacMillan, London.

Global Detention Project 2018, Immigration Detention in Lebanon: Deprivation of Liberty at the Frontiers of Global Conflict, viewed 11 September 2020, 
$<\underline{\text { https://www.globaldetentionproject.org/immigration-detention-in-lebanon-deprivation- }}$ of-liberty-at-the-frontiers-of-global-conflict>.

Gordon, P 1983, White Law: Racism in the Police, Courts and Prisons, Pluto Press, London.

Gorman, A 2007 'Regulation, Reform and Resistance in the Middle Eastern Prison' in F Dikötter \& I Brown (eds.) Cultures of Confinement: A History of the Prison in Africa, Asia and Latin America. Cornell University Press, Ithaca, New York, pp. 95-146.

Hall, R 2019, 'Lebanon's Labour Minister Likens Kafala System to “Modern Day Slavery” and Vows Reform', The Independent, viewed 11 September 2020, $<$ www.independent.co.uk/news/world/middle-east/lebanon-kafala-migrant-workerslabour-minister-camille-abousleiman-a8894056.html>.

Hamadah, F 2020, 'COVID and Kafala', MR Online, viewed 11 September 2020, $<$ https://mronline.org/2020/08/17/covid-and-kafala/>.

Hamill, K 2012, 'Policy Paper on Reforming the "Sponsorship system" for Migrant Domestic Workers: Towards an Alternative Governance Scheme in Lebanon', KAFA (Enough) Violence \& Exploitation, viewed $11 \quad$ September 2020, $<$ www.kafa.org.lb/sites/default/files/2019-02/Reforming_JKafalaSystemLeb_0.pdf>.

Harmassi, M 2009, 'Bahrain to End 'Slavery' System', BBC News, viewed 11 September 2020, $<$ http://news.bbc.co.uk/1/hi/world/middle_east/8035972.stm>.

Hester, M, Kelly, L \& Radford, J 1996, Women, Violence and Male Power: Feminist Activism, Research and Practice, Open University Press, Buckingham.

Human Rights Watch 2015, 'Bahrain: Abuse of Migrant Workers Despite Reforms', viewed 11 September 2020, <https://www.hrw.org/news/2012/09/30/bahrain-abuse-migrantworkers-despite-reforms $>$.

Human Rights Watch 2019, 'For a Better Life: Migrant Worker Abuse in Bahrain and the Government Reform Agenda', viewed 11 September 2020, <www.hrw.org/report/2012/09/30/better-life/migrant-worker-abuse-bahrain-andgovernment-reform-agenda $>$.

Hundle, AK 2019, 'Postcolonial Patriarchal Nativism, Domestic Violence and Transnational Feminist Research in Contemporary Uganda', Feminist Review, vol. 121, no. 1, pp. 37-52, DOI 10.1177/0141778918818835.

Insan Association 2016, ‘Trapped: Migrant Domestic Workers in Lebanon', viewed 11 September 2020, <https://www.insanassociation.org/en/images/Trapped.Compressed.pdf $>$. 
International Labour Organization 2012, 'Responding to Emerging and Critical Issues', Reform of the Kafala (Sponsorship) System, Policy Brief No. 2, viewed 11 September 2020, $<$ https://www.ilo.org/dyn/migpractice/docs/132/PB2.pdf $>$.

Jureidini, R 2002, 'Women Migrant Domestic Workers in Lebanon', International Migration Papers, no. 48, The International Labour Organization, viewed 11 September 2020, $<$ http://www.fudepa.org/Biblioteca/recursos/ficheros/BMI20060000461/imp48e.pdf>.

Jureidini, R 2010, 'Trafficking and Contract Migrant Workers in the Middle East', International Migration, vol. 48, no. 4, pp. 142-163, DOI 10.1111/j.1468-2435.2010.00614.x.

Lee, M, Johnson, M, \& McCahill, M 2018, 'Race, Gender and Surveillance of Migrant Domestic Workers in Asia' in M Bosworth, Y Vázquez \& A Parmar (eds.) Race, Criminal Justice and Migration Control: Enforcing the Boundaries of Belonging. Oxford University Press, Oxford, pp. 13-28.

Mahdavi, P \& Sargent, C 2011, 'Questioning the Discursive Construction of Trafficking and Forced Labour in the United Arab Emirates', Journal of Middle East Women's Studies, vol. 7, no. 3, pp. 6-35, DOI 10.2979/jmiddeastwomstud.7.3.6.

Massena, F 2020, 'Trapped in Lebanon: Fears of Abuse for Migrant Domestic Workers Amid Covid-19 Lockdown', The New Arab, viewed 11 September 2020, $<$ https:/english.alaraby.co.uk/english/indepth/2020/4/10/for-domestic-workers-lebanonlockdown-a-recipe-forabuse? fbclid=IwAR0TixWFLKVMNmH9T9tOpEByOkY0hQsh83pLzW06hLG1AtZ0rS 3GldJRPMo $>$.

Migrant Rights 2018, 'Assessing Bahrain's New Standard Contract for Domestic Workers', viewed 11 September 2020, <www.migrant-rights.org/2018/03/assessing-bahrains-newstandard-contract-for-domestic-workers/>.

Mirza, N 2016, 'The UK Government's Conflicting Agendas and "Harmful” Immigration Policies: Shaping South Asian Women's Experiences of Abuse and "Exit", Critical Social Policy, vol. 36, no. 4, pp. 592-609, DOI 10.1177/0261018316641239.

Pande, A 2013, 'The Paper that you Have in your Hand is my Freedom: Migrant Domestic Work and the Sponsorship (Kafala) System in Lebanon', International Migration Review, vol. 47, no. 2, pp. 414-441, DOI 10.1111/imre.12025.

Perry, M 2006, 'Perceptions of Race in the Arab World', viewed 11 September 2020,

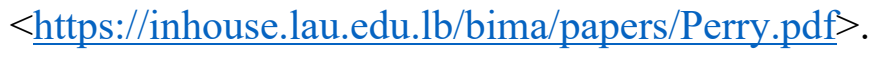

Pickering, S 2007, 'Transnational Crime and Refugee Protection', Social Justice, vol. 34, no. 2, pp. 47-61, viewed 11 September 2020, <https://www.jstor.org/stable/29768434>. 
Radford, J \& Russell, DEH 1992, Femicide: The Politics of Woman Killing. Open University Press, Buckingham.

Shalhoub-Kevorkian, N 2003 'Re-examining Femicide: Breaking the Silence and Crossing "Scientific" Borders', Signs: Journal of Women in Culture and Society, vol. 28, no. 2, pp. 581-608, DOI 10.1086/342590.

Shalhoub-Kevorkian, N \& Daher-Nashif, S 2013, 'Femicide and Colonization: Between the Politics of Exclusion and the Culture of Control', Violence against Women, vol. 19, no. 3, pp. 295-315, DOI 10.1177/1077801213485548.

Sokoloff, NJ \& Burgess-Proctor, A 2011, "Remembering Criminology's "Forgotten Theme": Seeking Justice in US Crime Policy Using an Intersectional Approach' in M Bosworth \& C Hoyle (eds.) What is Criminology?. Oxford University Press, Oxford, pp. 236-248

Strobl, S 2008, 'Policing Housemaids: The Criminalisation of Domestic Workers in Bahrain', British Journal of Criminology, vol. 49, no. 2, pp. 165-183, DOI 10.1093/bjc/azn071.

Su, A 2017, 'Slave Labour? Death Rate Doubles for Migrant Domestic Workers in Lebanon', The New Humanitarian, viewed $11 \quad$ September 2020 , $<$ https://www.thenewhumanitarian.org/feature/2017/05/15/slave-labour-death-ratedoubles-migrant-domestic-workers-lebanon>.

Sykes, GM \& Matza, D 1957, 'Techniques of Neutralization: A Theory of Delinquency', American Sociological Review, vol. 22, no. 6, pp. 664-667, DOI 10.2307/2089195.

Wade, L 2011, 'Learning from "Female Genital Mutilation”: Lessons from 30 Years of Academic Discourse', Ethnicities, pp. 24-49, DOI 10.1177/1468796811419603. 